\title{
IIIT Intellectual Panels
}

The International Institute of Islamic Thought (IIIT) organized a two-day series of intellectual panels at the Islamic Society of North America's 51st annual convention, held in Detroit during August 30-31 2014. These events were hosted in the institute's hospitality suite on the third floor of the Cobo Center.

Session 1: Reform of Education

Ebrahim Moosa (University of Notre Dame) contended that Islamic thought and education have stagnated due to Islamic institutions' fear that secular education will have a negative influence on Muslim education. Arguing that modern and madrasa education should not be seen as separate entities, he urged Muslims to experiment with new ideas and explore new possibilities and innovations and to overcome this "trap for censorship" that prevents them from accessing the knowledge required to ask deeper questions about the role of ethics in our educational models. Since "excellence must be sought - one must read everything and learn everything and not be censored in this pursuit," He challenged Muslim educational organizations and scholars to transcend questions of paradigm and method and get "knee deep in the production of learning and seeking knowledge." Moosa concluded by warning that a hypercautious attitude can become the enemy of innovation and reform.

Imam Zaid Shakir (Zaytuna College) reflected upon the state of American secondary school education by citing the consistently low ranking of American high students' mathematical ability on the word stage. After highlighting the lack of discipline found in many high schools, which have "become places teenagers hang out but are not particularly challenged," he remarked that if 
high schools were more academically challenging, students would rise to that challenge. He described how Zaytuna equips its students to become lifelong learners by building upon a traditional Islamic education, argued for more emphasis on memorization, reiterated the need for ethical integration, and stressed the imperative of a faculty with diverse backgrounds and pedigrees.

Mahan Mirza (Zaytuna College), looking at educational reform from a global perspective, sought to illustrate how reason is the thread that links humanity together. Rather than concentrating mainly on vocational training, he urged educational institutions to focus on creating moral human beings, for "it is through self-cultivation that creativity and innovation is created." $\mathrm{He}$ recommended centering reform on human rights principles (everyone has the right to an education) and that education should develop the person's full potential. In short, institutions should focus on the liberal arts. Mirza concluded by emphasizing Zaytuna's liberal arts model, which engages the Islamic and the Western intellectual traditions, for they both seek to answer the same humanistic questions.

Expanding further, Ingrid Mattson (Huron University) talked about building Muslim students' intellectual capacity. "Where," she asked, "are Muslims in the United States being educated?" She provided several answers: they first engage Islamic studies at Sunday school, and then rhetorically infused Friday sermons, social and traditional media, and primarily through Google. She argued that the ensuing misconceptions leave a very hard-to-overcome kind of neurological imprint. As a teacher, Mattson sees her most important responsibility as helping her students use their minds to both correct and increase their knowledge. She also warned against depending upon charismatic leaders stating that what students are really looking for is a mentor in the form of a teacher who can provide identity formation along with a safe environment for discussion, growth, and debate. She concluded by explaining how storytelling connects us to the wisdom of the past, diversifies the voices heard in our discourses, and prevents us from regarding the documented text alone as authoritative.

Ermin Sinanovic IIIT) ended the session by articulating IIIT's mission and focus on reforming Islamic education by bringing together diverse scholars to address the issue of contemporary Islamic education. Abubaker AlShingieti (IIIT) moderated.

Session 2: Reflections on the Post Arab Spring Era.

Emad Shahin (Georgetown University), who addressed the Arab Spring protesters' demands for freedom, dignity, and emancipation, stressed the importance of the word emancipation. He remarked how the movement's rapid 
spread showed a collective consciousness to overthrow existing power structures and noted the protesters' pride in its transcendent nature and pluralistic leadership. He then addressed the current situation, highlighting Egypt's new authoritative regime, and remarked that it resembles a smoldering volcano. After wondering out loud about the region's future, he predicted that the Arab Spring would have an lasting impact because of the unprecedented number of protesters, young people's ability to mobilize the people and use public spaces, and ordinary people's ability to transcend their fear. Shahin concluded by remarking how much el-Sisi's regime resembles Mubarak's and mentioned the MENA region's ongoing challenges (e.g., water and food shortages, the population explosion, the disparity between rich and poor nations, labor market reforms, ongoing instability, and the need for real democracy).

Discussant Ermin Sinanovic (IIIT) made several observations: It was interesting that single-party authoritarian regimes collapsed and monarchies did not, that the protesters and people in general must not be idealize what has been going on, whether the large numbers indicate a collective will or simply imitation, and that external factors (e.g., the international constellation of power and the survival of the nation-state system) are also in play. In closing, he stressed the importance of infusing ethical discourse in Islamic thought instead of just using Islamic opinions to justify whatever fits in with one's personal agenda. Hishan Altalib (IIIT) moderated.

Session 3: Iftà' 'and Fatwa in the Muslim World and the West. Zulfiqar Ali Shah, ed. (IIIT: 2014)

Zulfiqar Ali Shah (Islamic Society of Milwaukee) opened by articulating the chaotic situation of ifta ' and fatwas worldwide and pointing out that unlike their classical peers, contemporary Muslim jurists seldom possess both disciplinary and societal knowledge, not to mention experience "with sophisticated scientific and social scientific research methods." Since a fatwa is the attempt to "apply the Shari'ah to the realities of daily life," this bifurcation leads to a social disconnect. Furthermore, jurists must contend with the online proliferation of fatwas, questions of religious authority, original legal methodologies that sometimes reflect a particular era's political and other realities, and the trend to generalize specific texts and to limit general ones. He then distinguished between two approaches: finding a relevant precedent from the Prophet and focusing on the ethical foundations underlying the texts and traditions. To better contextualize Islamic sources for interpretation, Shah wondered whether the ulama' could develop an asbāb al-nuzūl-type discipline for the hadiths. 
The first discussant, Jamal Badawi, echoed Shah's call for better contextualization, elaborated on the issue of apostasy, and cautioned against overgeneralizing the malaise of contemporary Muslims jurists. Muhammad Nur Abdullah (Fiqh Council of North America) stressed the need for collective $i j t i h \bar{a} d$ due to the very specialized nature of contemporary knowledge. Ihsan Bagby (University of Kentucky) synthesized the previous panelists, focused on iftā's continuing importance to Muslim culture (especially as a tool of argumentation), and pointed out that Muslim jurists should be more concerned with producing better quality arguments than remaining fixated on pedigrees. Iqbal Unus (IIIT) moderated.

\section{Session 4: IIIT Distinguished Scholar Award}

Emad Shahin was honored for his prolific academic and intellectual career at the American University of Cairo, Georgetown University's School of Foreign Service, and Columbia University. His commentary in media and numerous forums exemplify a deep engagement with and commitment to justice, freedom, and human rights. Abubaker al-Shingieti moderated; Hisham Altalib presented the award.

\section{Session 5: IIIT Legacy Documentary}

Documentary producer Alex Kronemer (Unity Productions Foundation) stated that he believes in the power of stories and that Muslims need to tell their own stories. He was inspired by Hisham Altalib, Jamal Barzinji, and M. Yaqub Mirza. His documentary film relays the story of IIIT through the voices of its founding members, who talked about their personal and professional attempts to reform Islamic thought.

Session 6: Answering the Call: Popular Islamic Activism in Sadat's Egypt. Abdullah Al-Arian (Oxford University Press: 2014)

Abdullah al-Arian (Georgetown University) stated that we rarely see images of communal-based Islamic activism. Tracing the history of the Muslim Brotherhood, he analyzed how the generation of secondary and university students, in marked contrast to the old generation, became student union leaders and, later on, leaders of professional syndicates. After explaining their ability to prioritize new forms of engagement by combining this type of activism with an explosion in print culture that focused on the global plight of Muslims and issues of Islamic praxis, he followed the Brothers's activities up to the present day. In Al-Arian's view, the elders' rigid structure prevented the younger generation's radicalization but also hindered their ability to navigate post-revolutionary Egypt As their organizational leadership shifts, Al-Arian concluded 
that these generational dynamics are essential for understanding the movement's trajectory.

Discussant Sinanovic emphasized that Al-Arian's research provides an important corrective his research provides to the literature, which seems to imply that the Brothers and similar groups focus too much on such issues as Israel, the West, and the role of women. He also asked, "What is it about the international order and global politics that enabled similar outcomes in Muslim-majority societies around the world during the same period?" Discussant Emad Shahin echoed Sinanovic's praise of how much this book contributes to contemporary discourse, especially since this period is quite understudied. He stated that its humanistic style enables the reader to connect with the struggle of individual activists. Hisham Altalib moderated.

Session 7: Five Pillars of Prosperity: Essentials of Faith-Based Wealth Building. M. Yaqub Mirza (White Cloud Press: 2014)

Yaqub Mirza (Sterling Management Group, Inc.) shared the principle that has guided his financial philosophy: avoiding debt. In his analysis of the five pillars, namely, earning, investing, spending, saving, and giving, he remarked that we should always do our best, track our spending, delay immediate gratification, and pursue financial security. He mentioned how one should start investing as early as possible, an activity that Islamic mutual funds have made much easier. Interestingly, Mirza spent most of his time relating how giving (while alive) should become a habit. Since the purpose of zakat is to eradicate poverty, we can conclude that it is not being collected and distributed adequately. He closed by pointing out that wills should be better utilized and the benefits of setting up limited family partnerships to distribute income among children more equitably.

Discussant Miles Davis (Shenandoah University) remarked that since business schools do not teach personal finance, this book should be required for all Americans. He finished by stating that Islam allows Muslims to "do good while doing well" due to its emphasis on intention. Discussant Imrana Umar (Powersim Solutions) concluded the session by mentioning that he would have titled the book The Five Pillars of Living because it reveals how one can move out of a state of dependency. Jawaad Abdul Rahman (Unity Productions Foundation) moderated.

Muhammad Siddiqui

Presidential Fellow, Office of the Dean Wake Forest Univ., Winston-Salem, NC Non-Resident Research Fellow IIIT
Courtney Dorroll Visiting Instructor, Department of Religion Wofford College, Spartanburg, SC Non-Resident Research Fellow IIIT 